\title{
Effect of organizational commitment on compassionate care behaviour of health care professionals
}

\author{
Kousar Parveen ${ }^{1 *}$, Muhammad Afzal ${ }^{1}$, Syed Amir Gillani ${ }^{1}$ and Amina \\ Arif $^{2}$ \\ 1. Faculty of Allied Health Sciences, The University of Lahore-Pakistan \\ 2. Faculty of life sciences, University of central Punjab, Lahore-Pakistan \\ *Corresponding author's email: kous84@gmail.com
}

Citation

Kousar Parveen, Muhammad Afzal, Syed Amir Gillani and Amina Arif. Effect of organizational commitment on compassionate care behaviour of health care professionals. Pure and Applied Biology. Vol. 9, Issue 2, pp1396-1404. http://dx.doi.org/10.19045/bspab.2020.90146

\begin{tabular}{llll}
\hline \hline Received: 07/08/2019 & Revised: 05/01/2020 & Accepted: 18/01/2020 & Online First: 26/02/2020 \\
\hline \hline
\end{tabular}

\section{Abstract}

The healthcare sector in developing countries, is striving to provide quality healthcare services where healthcare professionals should treat the patients with compassion, dignity, attention, and respect. To achieve such objectives, the recent research highlights the key role of compassionate care behaviour in healthcare sector. However, little attention has paid to investigate factors that augment compassionate care behaviour among healthcare professionals. Therefore, the current study marks the first attempt to examine the effect of organizational commitment on compassionate care behaviour. The study design was cross-sectional and questionnaire distributed to 340 healthcare personnel through convenient random sampling. Moreover, confirmatory factor analysis was used to check data reliability and validity while regression analysis was used to test proposed hypothesis. Out of 340 subjects, 330 (97.0\%) were female and $10(03.0 \%)$ male health care professionals working in indoor units. Majority of the participants belonged to age bracket 24-32 years (40\%) and 33-41 years (43\%) while remaining $17 \%$ from age group 42-60 years. A statistically significant association was found among organizational commitment and compassionate care behaviour $(\mathrm{p}<0.05)$. Conclusion: The current study findings revealed significant positive relationship between organizational commitment and compassionate care behaviour of health care professionals. The Current study marks the first attempt to delineate the role of organizational commitment to enhance compassionate care behaviour among healthcare personnel which offers several implications for nursing administration, human resource managers and hospital management.

Keywords: Compassionate Care; Healthcare professional; Hospital management;

Organizational commitment

\section{Introduction}

Compassion is a profound feeling, elicited by viewing the pain and distress of others, and trying to alleviate the suffering of others in pain [1]. Compassion is a core value in health care sector. Compassion is valuing and respecting the patient as individuals and answering in the ways to relive suffering of those in distress of health care need [2].Compassion connotes a deep connection with someone's suffering accompanied by the intention to act to alleviate that suffering $[3,4]$. Moreover, compassion in care is central concepts for the healthcare professionals and described as "healthcare most valuable asset" [5]. 
Indeed, compassion towards humanity is viewed as basics for provision of excellent quality patient care [6]. Compassion play an important role to unit sufferers in difficult times and healthcare providers acts to promote the physical and mental health of those in difficult times [7]. Compassion is a Latin word means suffer with. The concept of suffering is obvious in the many definitions of compassion, where the healthcare provider views are that the suffering of others are their suffering and they try to mitigate this suffering $[8,9]$. Health care professionals identify and deliberately acts to alleviate the suffering of those in pain [10].

Compassionate care is one of the most emerging research area in healthcare sector and management. It has two components: first you have awareness of another's suffering and then you must response or act appropriately to relieve [5]. Moreover, Compassionate Care has been defined as a construct which connotes a profound acknowledgment of other's distress of suffering accompanied by intent to alleviate their sufferings [11]. Compassion has two fundamental qualities; kindness and action. Healthcare professional showed kindness in the form of sympathetic awareness of others' suffering, with an action to minimize it. Moreover, Compassionate Care is the immersion into another's suffering, pain, brokenness even though that person is a stranger [12].

Compassion is a fundamental philosophy to the every healthcare profession in the provision of best quality patient care [4]. However, in this contemporary era, compassionate interactions in the health care sector is desirable. Despite its profile, little research has investigated how compassionate care is enacted and influenced by organizational factors. The literature, however, suggests to incorporate organizational commitment (OC) as organizational construct that has strong influence on compassionate care the dependent variables of interest. Organizational commitment (OC) is psychological bond employees' feel towards the goals of the organization [13]. Through organizational commitment employees feel themselves as a part of an organization. Furthermore, extant literature characterizes organizational commitment in three ways; readiness to accept organizational goals and aims, readiness to exercise substantial efforts to achieve goals and a definite desire to be member of an organization $[14,15]$.

The three component model of Meyer \& Allen stipulates affective, continuous, and normative as basic types of organizational commitment $[1,16]$. Moreover, the Latin word affective means emotions, feelings and attitude. Affective commitment is an emotional connection with organization which enables the workforce to feel honour to tell others that they are the part of the organization. In addition, workforce having affective commitment want to stay and retain in the same organization for long run [17-19].

Likewise, employees with normative commitment show professional loyalty or obligation to stay in the organization in response to employer's investment in form of training [8]. Affective and normative commitment consistent to each other. Consequently, the effects of normative commitment on organizational outcome not significantly different from affective commitment [2]. In contrast, continuous commitment means employees have to stay because of disbursement associated with leaving the organization [5]. The reasons of employee's perceived cost or disbursement include loss of fringe benefits, not getting the better job, family relocation cost and loss of opportunities for promotion [7]. As a large body of research demonstrates that organizational commitment influence behavioural outcomes namely loyalty, motivation, engagement, compassion, turn over intentions, and citizenship behaviours $[19,20]$. Therefore, the current study aimed to examine the impact of organizational commitment (OC) on compassionate care (CC) practice of health care professionals. 
In doing so, current study advances the body of knowledge on an emerging stream of research and contributes to scholarly discourse which endeavours for in-depth understanding of organizational commitment and compassionate care practice.

\section{Materials and methods}

A cross sectional design was used. Demographic Characteristics of Respondents are given in (Table 1). Target population was health care personnel having continuous contact with the patient of Services Hospital Lahore, Pakistan. Sample size was estimated as 340 healthcare personnel. The investigator would not factor analyse a sample until the sample size preferably should be 100 or large for quantitative studies. As a rule of thumb, minimum is to have five times observation as the number of constructs/ variables. The researcher tries to take highest cases-per- variable ratio to reduce the chances of overfitting the collected data [21]. Therefore, Registered Nurses of Services Hospital having continuous contact with the patients were accessed conveniently. We distributed 500 questionnaires to Registered Nurses and received 365 filled questionnaire from which 25 were not considered for data analysis because of incomplete responses. Finally, we used 340 complete responses for final data analyses. Inclusion criteria of the study was Registered Nurses of Services hospital having continuous contact with the patient. Ethical permission was taken from the institutional review board (IRB) committee of the University of Lahore. Moreover, Informed consent was signed by the participants before giving data. Confidentiality of the participants was maintained and assured.

The measures of all constructs were adopted from prior literature. A structured questionnaire of Organizational Commitment (OC) and Compassionate Care (CC) were used to collect data from registered Nurses. The questionnaire was distributed to the participants by the researcher. Organizational Commitment was measured with 08 item scale of Allen and Meyer (1996). We adopted 12 items measure of Compassionate Care from previous study [22]. The response of all 20 items was taken on seven point mostly ranging from $1=$ strongly disagree/ not successful to $7=$ strongly agree/ very successful on likert scale. Statistical analysis was done with SPSS software (version 24). The holistic view of the study findings, reliability and validity testing were performed by regression analysis shown in (Table 2) and Confirmatory factor analysis (CFA) given in (Table 3). Regression and correlation analysis was used to examine the impact of organizational commitment (0C) on compassionate care (CC) practice of healthcare personnel.

\section{Results}

Demographic characteristics of respondents are given in (Table 1). As reported in (Table 2) demographic analysis showed that data comprises of one percent $(\mathrm{N}=10)$ males and 99 percent $(\mathrm{N}=330)$ females health care personnel. Mostly respondents hold diploma (65\%) and graduate degree healthcare personnel $(34 \%)$. Majority of the participants belong to age bracket 33-41 years (43\%) and 24-32 years $(40 \%)$ while remaining $17 \%$ from age group 42-60 years. All of the respondents are from public sector. Besides above demographic information, we inquired about respondents' years of experience with organization. Experience of respondents range from 1-5 years (35.6\%), 6-10 years (35\%), 11- 15 years (25\%) and only small number of respondents have experience from 16-20 years (4\%).

The Cronbach-alpha value for reliability of every construct is greater than 0.70 which indicates high consistency among different items. Confirmatory factor analysis (CFA) given in (Table 3 ).

The statistics of CFA indicates the suitability of collected data for further analysis as it meets criteria for reliability and validity. The data fulfils the 
requirements of reliability and validity. Moreover, factor loading values pertaining to individual items are higher than 0.50 that provide support for convergent validity. In addition, the values of average variance extracted for almost all the measures are higher than 0.5. Additionally, Cronbachalpha value for every construct reliability is greater than 0.70 which indicates high consistency among different items. Correlation among different study variables is provided in (Table 4).

Table 4 showed correlation among different study variables. Results confirmed that organizational commitment (OC) has significant positive correlation with nurses' compassionate care (CC) at level of significance $(\mathrm{p}=0.000)$ and $(\mathrm{r}=0.584)$.
The Regression analysis reported in (Table 5) specifies that Organizational Commitment significantly contributes in the provision of Compassionate care with 0.711 of beta, $\mathrm{R} 2=0.506$, and $\mathrm{P}$ (sign.) $=$ 0.00 . F-statistic value of 207.32 with level of significance 0.00 , supporting the hypothesis that organizational commitment (0 C) has significant positive effect on compassionate care. Unstandardized and Standardized Coefficients are represented in (Table 6). Where the significant value is 0.000. Thus, it is concluded that organizational commitment imposes great effect on compassionate care health care personnel.

Table 1. Demographic characteristics of respondent

\begin{tabular}{|c|c|c|c|}
\hline S\# & Demographic Characteristic & 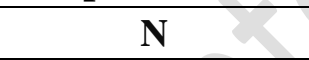 & $\%$ \\
\hline & & 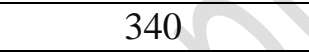 & $100 \%$ \\
\hline 1 & \multicolumn{3}{|c|}{ GENDER } \\
\hline & Female & 330 & 97.0 \\
\hline & Male & 10 & 03.0 \\
\hline 2 & \multicolumn{3}{|c|}{ EDUCATION } \\
\hline & Diploma Holders & 221 & $65 \%$ \\
\hline & 2 Year BS (Post RN) & 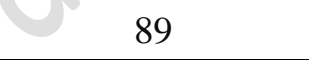 & $26.2 \%$ \\
\hline & 4 Year BS (Generic) & 27 & $7.9 \%$ \\
\hline & 2 Year MSN & 3 & 0.9 \\
\hline 3 & \multicolumn{3}{|c|}{ AGE GROUP } \\
\hline & 24 Year_32 Year & 135 & $39.7 \%$ \\
\hline & 33 Year_41Year & 145 & $42.6 \%$ \\
\hline & 42 Year_50 Year & 53 & $15.6 \%$ \\
\hline & 51Year_60 Year & 7 & 2.1 \\
\hline 4 & \multicolumn{3}{|c|}{ EXPERIENCE } \\
\hline & 1-5 Years & 121 & 35.6 \\
\hline & 6-10Years & 119 & 35.0 \\
\hline & 11-15Years & 86 & 25.3 \\
\hline & 16-20 Years & 14 & 4.1 \\
\hline 5 & \multicolumn{3}{|c|}{ SECTOR } \\
\hline & Public & 340 & 100.0 \\
\hline
\end{tabular}


Table 2. Reliability analysis

\begin{tabular}{|c|c|c|}
\hline \multirow{2}{*}{$\begin{array}{c}\text { Organizational } \\
\text { commitment }\end{array}$} & \multicolumn{2}{|c|}{ Reliability Statistics } \\
\cline { 2 - 3 } & Cronbach's Alpha & N of Items \\
\cline { 2 - 3 } & 0.919 & 8 \\
\hline \multirow{3}{*}{ Compassionate care } & & Reliability Statistics \\
\cline { 2 - 3 } & Cronbach's Alpha & N of Items \\
\cline { 2 - 3 } & 0.953 & 12 \\
\hline
\end{tabular}

Table 3. Statistics of Confirmatory Factor Analysis

\begin{tabular}{|c|c|c|c|}
\hline Constructs & Items & Factor Analysis & Cronbach-Alpha \\
\hline \multirow{8}{*}{$\begin{array}{l}\text { Organization } \\
\quad \text { al } \\
\text { Commitment }\end{array}$} & $\begin{array}{l}\text { I would be very happy to spend the rest of } \\
\text { my career with this organization. }\end{array}$ & 0.816 & \multirow{8}{*}{0.919} \\
\hline & $\begin{array}{l}\text { I enjoy discussing my organization with } \\
\text { people outside it. }\end{array}$ & 0.787 & \\
\hline & $\begin{array}{l}\text { I really feel as if this organization's } \\
\text { problems are my own. }\end{array}$ & 0.701 & \\
\hline & $\begin{array}{l}\text { I think that I could easily become as } \\
\text { attached to another organization as I am to } \\
\text { this one. }\end{array}$ & 0.758 & \\
\hline & $\begin{array}{c}\text { I do not feel like 'part of the family' at my } \\
\text { organization. }\end{array}$ & 0.793 & \\
\hline & $\begin{array}{c}\text { I do not feel 'emotionally attached' to this } \\
\text { organization. }\end{array}$ & 0.776 & \\
\hline & $\begin{array}{c}\text { This organization has a great deal of } \\
\text { personal meaning for me. }\end{array}$ & 0.765 & \\
\hline & $\begin{array}{l}\text { I do not feel a strong sense of belonging } \\
\text { to my organization. }\end{array}$ & 0.732 & \\
\hline \multirow{12}{*}{$\begin{array}{l}\text { Compassiona } \\
\text { te Care }\end{array}$} & $\begin{array}{l}\text { Express sensitivity, caring and } \\
\text { compassion for the patient's situation }\end{array}$ & 0.837 & \multirow{12}{*}{0.953} \\
\hline & $\begin{array}{c}\text { Strive to understand patient's emotional } \\
\text { needs }\end{array}$ & 0.846 & \\
\hline & $\begin{array}{l}\text { Consider the effect of illness on the } \\
\text { patient, patient's family, and the people } \\
\text { most important to the patient }\end{array}$ & 0.777 & \\
\hline & Listen attentively to the patient & 0.844 & \\
\hline & $\begin{array}{l}\text { Convey information to the patient in a } \\
\text { way that was understandable }\end{array}$ & 0.720 & \\
\hline & Gain patient's trust & 0.809 & \\
\hline & $\begin{array}{l}\text { Always involve the patient in decisions } \\
\text { about the treatment }\end{array}$ & 0.725 & \\
\hline & $\begin{array}{c}\text { Comfortably discuss sensitive, emotional } \\
\text { or psychological issues }\end{array}$ & 0.776 & \\
\hline & $\begin{array}{l}\text { Treat the patient as a person not just a } \\
\text { disease }\end{array}$ & 0.786 & \\
\hline & $\begin{array}{l}\text { Show respect for the patient, patient's } \\
\text { family and those important to the patient }\end{array}$ & 0.757 & \\
\hline & $\begin{array}{l}\text { Communicate test results in a timely and } \\
\text { sensitive manner }\end{array}$ & 0.808 & \\
\hline & $\begin{array}{l}\text { Express sensitivity, caring and } \\
\text { compassion for the patient's situation }\end{array}$ & 0.821 & \\
\hline
\end{tabular}


Table 4. Correlations

\begin{tabular}{|c|c|c|c|}
\hline & & O. Commitment & Compassionate care \\
\hline \multirow{3}{*}{$\begin{array}{l}\text { O. Commitment } \\
\text { (OC) }\end{array}$} & Pearson Correlation & 1 & $0.584 * *$ \\
\hline & Sig. (2-tailed) & & 0.000 \\
\hline & $\mathrm{N}$ & 340 & 340 \\
\hline \multirow{3}{*}{$\begin{array}{c}\text { Compassionate } \\
\text { care } \\
\text { (CC) }\end{array}$} & Pearson Correlation & $.584 * *$ & 1 \\
\hline & Sig. (2-tailed) & .000 & \\
\hline & $\mathrm{N}$ & 340 & 340 \\
\hline
\end{tabular}

**. Correlation is significant at the 0.01 level (2-tailed)

Table 5. Regression analysis

\begin{tabular}{|c|c|c|c|c|c|c|c|c|c|c|}
\hline \multicolumn{10}{|c|}{ Model Summary } \\
\hline $\begin{array}{c}\text { M } \\
\text { o } \\
\text { de } \\
1\end{array}$
\end{tabular}

Table 6. Coefficients representation

\begin{tabular}{|c|c|c|c|c|c|c|}
\hline \multirow{2}{*}{ Model } & \multicolumn{2}{c|}{$\begin{array}{c}\text { Unstandardized } \\
\text { Coefficients }\end{array}$} & $\begin{array}{c}\text { Standardized } \\
\text { Coefficients }\end{array}$ & \multirow{2}{*}{ T } & \multirow{2}{*}{ Sig. } \\
\cline { 3 - 6 } & B & Std. Error & Beta & & \\
\hline \multirow{2}{*}{1} & (Constant) & 2.198 & 0.134 & & 23.358 & 0.000 \\
\cline { 2 - 6 } & $\begin{array}{c}\text { Compassio } \\
\text { nate care }\end{array}$ & 0.313 & 0.030 & 0.711 & 6.332 & 0.000 \\
\hline
\end{tabular}

\section{Discussion}

The current study aimed to examine the effect of organizational commitment (OC) on compassionate care (CC) behaviour of health care personnel. Demographic data of the participants revealed that mostly females participated in this study. Similar finding depicted in the previous study, where the majority participants were females [17].

Health care personnels who rate high on commitment are expected to show devoutness to the needs of patients. As organizational commitment encourages care giving behaviour and enhances the well-being of those in pain. The plenty of literature states that organizational investments in the betterment of employees may provide employees with the impetus needed to remain motivated. These motivated employees desire to serve the public and contribute positively toward organizational goals [23-25]. The study findings indicated that organizational 
commitment influence the compassionate care behaviour of health care providers [26].

Organizational commitment positively relate with employees' public service motivation. Public service motivation is an indicator of performance in which individuals have a desire to serve the public and link their personal actions with the overall public interest. Likewise, compassionate care is also indictor of performance and important dimension of public service motivation. Public service motivation is an attitude that motivates employees to display prosocial behaviour $[18,27]$. Similarly, compassionate care (CC) is also indicator of performance so that it is supposed that Organizational commitment can also influence compassionate care behaviour of healthcare professionals.

Organizational commitment engendered from healthcare sector significantly influence nurse's compassionate care behaviour. This suggests that nurses are willing to care their patients compassionately, committed enough to express sensitivity, listen attentively, show respect to sensitive issues and convey information to the patient in sensible way. All these favourable intentions heavily depend on commitment level which emerged as the most productive dimensions to instigate compassionate care (CC).

As our study is the first of its kind that investigates the relationship Organizational commitment with compassionate care behaviour. Our results are consistent with earlier findings from service sector. Organizational commitment are positively related with proactive customer service performance. Compassionate Care is also an indicator of performance so it is aligned with Organizational commitment influence on compassionate care behaviour of healthcare professionals [21]. Organizational commitment influence the compassionate care behaviour of health care providers. The health care team members need to understand and provide care compassionately to the patients only when they are committed with the organization [24].

\section{Conclusion}

Current study advances the body of knowledge by exploring the organizational related factors like an organizational commitment that enhances compassionate care behaviour of health care personnel in public sector hospitals of a developing country. In this regard, the study findings indicated that the organizational commitment is the leading organizational practice to augment compassionate care behaviour that ultimately reduces the patient distress and healthcare sector prestige will be enhanced. Moreover, practically our study provides useful insights to the hospital administration and human resource managers. The hospital administration and human resource managers should use different highcommitment human resource practices as strategic imperative to attract best employees and enhance their motivation/commitment through developmental performance appraisal system. In addition, competitive and equitable compensation could further augment employees' level of commitment with the organization and instigate compassion for the clientele. The human resource department of healthcare sector should be equipped with insights to use selective staffing, equitable reward systems and performance appraisal as the dominating forces to recruit and motivate the health care personnel to provide effective care to the patient in committed manner. More importantly, ward mangers/ head nurses should utilized the committed employees to provide high quality nursing care to the patients. The committed workforce of nurses express sensitivity to patient in critical situations. This study also comes with some limitations. Firstly, we collected data only from nurses of one public sector hospital that might limit the generalizability of findings in private sector. Thus, future studies may consider to 
utilize observational/ experimental approach to collect data both from human resource managers and nurses of public and private sector to further enrich the topic. All the participants were nurses with professional qualification that may not reflect entirely the view of all other healthcare staff. Therefore further research should be done on other health care professionals to strengthen the compassionate care in different health care sectors. Though, there is a study that has examined two human resource practices with Nurse's turnover intention but they did not consider role of organizational commitment on compassionate care behaviour. Therefore, there's a dire need to study the relationship of organizational commitment with compassionate care in healthcare sector. In fact, the actual problem is the scarcity of research studies in the realm of organizational commitment in healthcare sector which motivates the authors to design this study to figure out how organizational commitment lead toward compassionate care behavior. Ward mangers/ head nurses should utilized the committed employees to provide high quality nursing care to the patients. The committed workforce of nurses express sensitivity to patient in critical situations.

\section{Authors' contributions}

Conceived and designed the experiments: $\mathrm{K}$ Perveen \& $M$ Afzal, Performed the experiments: K Perveen \& SA Gilani, Analyzed the data: M Afzal \& SA Gilani, Contributed reagents/ materials/ analysis tools: K Perveen \& A Arif, Wrote the paper:

\section{K Perveen.}

\section{References}

1. Mooney M, Glacken M \& O'Brien F (2018). Choosing nursing as a career: A qualitative study. Nurse Edu Today 28(3): 385-392.

2. Gilbert $P(2014)$. The origins and nature of compassion focused therapy. British J of Clinical Psychol 53(1): 6-41.

3. Osborn HF (1911). Florence Nightingale. The American J of Nursing 11(5): 339-341.
4. Straughair C (2012). Exploring compassion: implications for contemporary nursing. Part 1. British J of Nursing 21(3): 160-164.

5. Schantz ML (2017). Compassion: $a$ concept analysis. Paper presented at the Nursing forum.

6. Ozawa-de Silva BR, Dodson-Lavelle B, Raison CL, Negi LT, Silva B \& Phil D (2012). Compassion and ethics: scientific and practical approaches to the cultivation of compassion as a foundation for ethical subjectivity and well-being. J of Healthcare, Sci and the Humanities 2(1): 145-161.

7. Gilbert P (2010). The compassionate mind: A new approach to life's challenges: New Harbinger Publications.

8. Francis R (2013). Report of the Mid Staffordshire NHS Foundation Trust public inquiry: executive summary ( $\mathrm{Vol}$ 947): The Stationery Office.

9. Parliamentary GB \& Ombudsman HS (2011). Care and Compassion?: Report of the Health Service Ombudsman on Ten Investigations Into Nhs Care of Older People (Vol 778): The Stationery Office.

10. Kinnaird L (2015). Nurses: The Backbone of Health Services. The Florida Nurse 63(4): 1-1.

11. Tierney S, Seers K, Tutton E \& Reeve J (2017). Enabling the flow of compassionate care: a grounded theory study. BMC Health Serv Res 17(1): 174.

12. Townsend K, Lawrence SA \& Wilkinson A (2013). The role of hospitals' HRM in shaping clinical performance: a holistic approach. The Inter J of Human Reso Manag 24(16): 3062-3085.

13. Meyer JP, Stanley DJ, Herscovitch L \& Topolnytsky L (2002). Affective, continuance, and normative commitment to the organization: A meta-analysis of antecedents, correlates, and consequences. $J$ of $V o c$ Behav 61(1): 20-52. 
14. Mowday RT, Porter LW \& Steers RM (2013). Employee-organization linkages: The psychology of commitment, absenteeism, and turnover: Academic press.

15. Porter LW, Steers RM, Mowday RT \& Boulian PV (1974). Organizational commitment, job satisfaction, and turnover among psychiatric technicians. J of Appl Psychol 59(5): 603.

16. Allen NJ \& Meyer JP (1996). Affective, continuance, and normative commitment to the organization: An examination of construct validity. $J$ of Vocational Behavior 49(3): 252-276.

17. Bramley L \& Matiti M (2014). How does it really feel to be in my shoes? Patients' experiences of compassion within nursing care and their perceptions of developing compassionate nurses. $J$ of Clinical Nursing 23(19-20): 2790-2799.

18. Mostafa AMS, Gould-Williams JS \& Bottomley P (2015). High-performance human resource practices and employee outcomes: the mediating role of public service motivation. Public Admin Rev 75(5): 747-757.

19. Saiki RK, Scharf S, Faloona F, Mullis KB, Horn GT, Erlich HA \& Arnheim N (1985). Enzymatic amplification of beta-globin genomic sequences and restriction site analysis for diagnosis of sickle cell anemia. Sci 230(4732): 1350-1354.

20. Blau P (2017). Exchange and power in social life: Routledge.
21. Chen M, Lyu Y, Li Y, Zhou X \& Li W (2017). The impact of highcommitment HR practices on hotel employees' proactive customer service performance. Cornell Hospitality Quarterly 58(1): 94-107.

22. Hair Jr JF, Babin BJ \& Anderson RE (2010). A GLOBAL P-ERSPECT-IVIE

23. Lown, B. A., Muncer, S. J., \& Chadwick, R. (2015). Can compassionate healthcare be measured? The Schwartz Center Compassionate Care Scale ${ }^{\mathrm{TM}}$. Patient Edu and Counseling 98(8): 1005-1010.

24. Cole-King A \& Gilbert P (2014). Compassionate care: the theory and the reality Providing Compassionate Healthcare, Routledge, pp 94-110.

25. Jiang K, Lepak DP, Hu J \& Baer JC (2012). How does human resource management influence organizational outcomes. A meta-analytic investigation of mediating mechanisms. Acad of Manag J 55(6): 1264-1294.

26. McClelland LE \& Vogus TJ (2014). Compassion practices and HCAHPS: does rewarding and supporting workplace compassion influence patient perceptions. Health Serv Res 49(5): 1670-1683.

27. Gould-Williams JS, Bottomley P, Redman T, Snape E, Bishop DJ, Limpanitgul T \& Mostafa AMS (2014). Civic duty and employee outcomes: do high commitment human resource practices and work overload matter. Public Admin 92(4): 937-953. 